\title{
Werner W. Franke: Congratulations on the occasion of his eightieth birthday
}

\author{
Klaus Unsicker ${ }^{1}$
}

Published online: 23 December 2019

(C) Springer-Verlag GmbH Germany, part of Springer Nature 2019

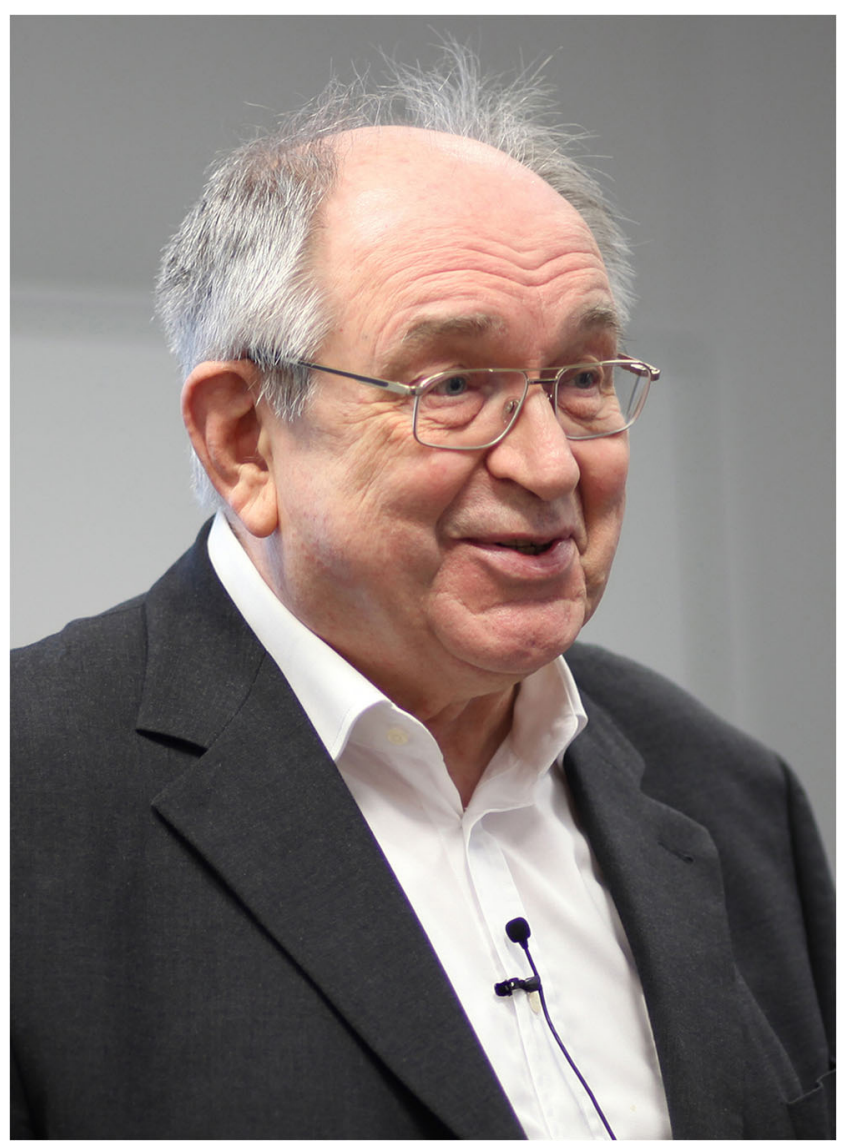

Cell and Tissue Research (CTR), its sections and cooperating editors congratulate Werner Franke who celebrates his eightieth birthday on January 31, 2020. On meeting him and talking to him, you would certainly not gain the impression of a

Klaus Unsicker

klaus.unsicker@anat.uni-freiburg.de

1 Institute of Anatomy \& Cell Biology, University of Freiburg, Albertstr. 17, D-79104 Freiburg, Germany scientist and university professor in retirement. Being active in the laboratory and generating new ideas for interesting experiments, he remains the highly dynamic personality that he has always been throughout his lifetime and hopefully will continue to be for many more years to come. As someone who still enjoys excellent science, he is always ready to join any battle necessary to combat bad science, taking on those who lack a sense of the meaning of excellent science, who want to replace basic science by "translational" science and who forget that science is based on excellent brains that never stop asking questions about the way that science, and especially biology, works. Thus, he continues to be the colleague with the sharp analytical understanding that we highly esteem and a greatly respected working member of the CTR Editorial Board. He is an internationally acknowledged expert in many diverse fields of cell biology, most notably the cytoskeleton, and is currently head of the Helmholtz Senior Group for Cell Biology at the German Cancer Research Center (DKFZ) in Heidelberg.

Werner Franke was born in Paderborn, East Westphalia, a region that, as claimed by Werner, generates more self-willed headstrong personalities than any other part of Germany. He studied Biology, Chemistry and Physics at Heidelberg University and afterwards moved to Freiburg University to take up an Assistant and Associate Professorship. At the age of 33, he was appointed Professor of the Faculty of Biology and Head of Division at the DKFZ Heidelberg. There, he began to study filaments and junctions of various cell types in relation to their states of differentiation and malignancy, making hallmark discoveries concerning, for example, keratins and vimentin. Preferentially, his research was "anti-dogmatically" oriented, being directed towards diverse kinds of cell-cell adhering junctions that are often not found in textbooks. He worked on many types of cell functions in relation to cell filaments and adherent junctions, such as the spreading, invasion and metastasis of tumour cells and their transdifferentiation. Important tools in his research were a wide range of antibodies, many of which are now used globally for scientific and diagnostic purposes. 
His research brought Werner Franke worldwide recognition, honours and awards. For a decade, he was the Associated Editor of the Journal of Cell Biology (JCB) for Europe, acted as a JCB Board Member for 27 years and served on the Editorial Board of many more prestigious journals, for example Biochemistry, Cell, Differentiation, EMBO Journal Experimental Cell Research, European Journal of Cancer, European Journal of Cell Biology and Journal of Cellular and Molecular Medicine. He was president, vice-president and chairman of many learned societies, advisory boards and granting bodies, including the European Cell Biology Organization (ECBO), the International Federation of Cell Biology, the International Society of Differentiation, the German Society for Cell Biology and the Conseil Scientifique of the Institut Curie, Paris. He is a member of EMBO, the Heidelberg Academy of Science and Humanities and many other distinguished societies. Among the prizes that he received are the Meyenburg Prize for Cancer Research, the Ernst Jung Prize, the Anders Retzius (Karolinska), Feulgen, Tinsley R. Harrison, Carl Zeiss and Hans Bloemendahl Lectures, the Feldberg Prize, the German Cancer Prize and very recently, the Thannhauser Medal of the German Society for Gastroenterology. Moreover, he is not only an outstanding researcher but also an inspiring lecturer; in 2017, he was elected "Professor of the Year" of the German Academic Association (Bonn). The ISI index reveals that Werner Franke has published over 660 original articles; indeed, he is among the most cited cell and molecular biologists worldwide and was listed in 2001 in the Highly Cited Researchers Database of the Institute for Scientific Information/Thomson
Scientific, Philadelphia, in the category Molecular Biology and Genetics.

Werner Franke often crossed the borders of the academic world going into the public domain. He was the co-founder of the company Progen in Heidelberg, which has its focus on molecular diagnostics. In Germany and beyond, Werner Franke is also known as a fighter against doping and a whistle-blower against all sorts of drug abuse in competitive sport. Together with his wife, Brigitte Berendonk, he uncovered not only government-sponsored doping in the former German Democratic Republic but also drug abuse in sport in the western part of Germany. With no signs of becoming tired, he has exploited the spirit of his own sportsmanship - he was an athlete in his younger years - and continues arguing and fighting against doping at all levels, through the media, committees and courtrooms.

Comprehensive praise of Werner Franke's achievements and mention of the abundance of merits that he has accumulated over 80 years is almost impossible. However, from the CTR perspective, one more acclamation is certainly required: it is wonderful to have Werner as a Section Editor for "Molecular/Cell Biology", to have him on the Editorial Board and to benefit from his analytical strength and uncompromising advocacy for quality and honesty in science.

Werner-thank you! We wish you many happy returns of the day. Ad multos annos!

Klaus Unsicker

and the members of the CTR Editorial Board 